\title{
$\therefore$ \\ A Study on the Variations of Pterion in Human Crania in Odisha
}

IJCRR

Section: Healthcare

ISI Impact Factor

(2019-20): 1.628

IC Value (2019): 90.81

$\operatorname{SJIF}(2020)=7.893$

(c) (7) (8)

Copyright@IJCRR

\section{Singh G' ${ }^{1}$ Das $\mathbf{S}^{1}$, Das SR ${ }^{2}$, Patra $\mathbf{M}^{3}$, Shamal SN ${ }^{3}$}

\begin{abstract}
'Assistant Professor, Department of Anatomy, Kalinga lnstitute of Medical Sciences, Bhubaneswar, India; ${ }^{A}$ Associate Professor, Department of

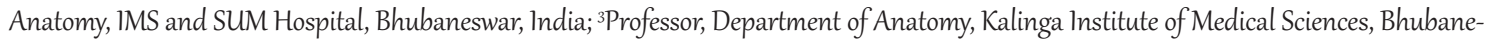
swar, lndia.
\end{abstract}

\section{ABSTRACT}

Introduction: Pterion is $\mathrm{H}$ shaped junction of sutures seen on norma lateralis where frontal, parietal, sphenoid and temporal bones meet. It has been described to be of four types - Sphenoparietal, Frontotemporal, Stellate and Epipteric types. Its position has been described to be located $2.6 \mathrm{~cm}$ behind fronto zygomatic suture and $4 \mathrm{~cm}$ above the zygomatic arch.

Objective: To assess the different types of pterion and to determine its exact location in dry adult human crania and to determine the variation in pteria between two sides and between males and females.

Methods: This study was conducted in the Department of Anatomy, Kalinga Institute of Medical Sciences, Bhubaneswar, Odisha using 50 dried human crania with the aims to assess the different types of pterion and to determine its exact location and to determine the variation in pteria between two sides and between males and females.

Results: The most common type of pterion was Sphenoparietal (80\%) followed by Epipteric (10\%), Stellate (10\%) and Frontotemporal $(0 \%)$ types. There was no side difference in the distance between pterion and frontozygomatic suture and between pterion and zygomatic arch. There was a gender difference ( $p$-value $=0.00033$ ) in the distance between pterion and zygomatic arch.

Conclusion: Pterion is an important anatomical region for neurosurgeons, anatomists, anthropologists and forensic experts.

Key Words: Pterion, Crania, Sphenoparietal, Frontozygomatic suture, Zygomatic arch, Suture

\section{INTRODUCTION}

Knowledge of the anatomy of pterion is essential for accurate positioning of burr holes for evacuation of extradural haematomas. Craniotomy in the region of pterion is performed for surgical approach to anterior and middle cranial fossae. ${ }^{1}$ Variation in the location and shape of pterion has been reported to occur between the two sides, among individuals, between the two sexes and different races. But these data in the Odisha population is lacking.

The pterion is a roughly $\mathrm{H}$-shaped junction of sutures formed by the meeting of four bones i.e frontal bone, greater wing of sphenoid, parietal bone and squamous part of temporal bones. It is related closely to the anterior branch of the middle meningeal artery and lateral fissure of the cerebral hemisphere. The location of pterion corresponds to the anterolateral fontanelle which is seen in neonates and closes in the $3^{\text {rd }}$ month of life after birth. It is located about $2.6 \mathrm{~cm}$ behind and $1.3 \mathrm{~cm}$ above the posterolateral margin of the frontozy- gomatic suture and about $4 \mathrm{~cm}$ above the midpoint of the zygomatic arch. ${ }^{1}$

According to the classification given by Murphy, there are four types of pterion: Sphenoparietal type (Figure 1). The greater wing of the sphenoid and the anteroinferior angle of parietal bones join directly in this type of pterion. Frontotemporal type - Frontal and temporal bones contact directly in this type of pterion. Stellate type (Figure 2). The tips of all four bones join in this type of pterion which resembles a star-like an appearance. Epipteric type (Figure 3) One or more sutural bones are present between the anteroinferior angle of the parietal and the greater wing of the sphenoid in this type of pterion. This sutural bone is also called epipteric bone. The presence of epipteric bones is of little morphological significance. The presence of epipteric bones can be due to normal process or rapid expansion of cranium in cases of hydrocephalus or genetic causes. ${ }^{1,2}$

This study was conducted with the aims to assess the differ-

\section{Corresponding Author:}

Das SR, K-8 Kalinga Nagar, IMS and SUM Hospital Ghatikia, Bhubaneswar, India.

Phone: 09439921177; Email: saurjyadas@gmail.com

ISSN: $2231-2196$ (Print)

Received: 24.09 .2020
ISSN: 0975-5241 (Online)

Revised: 18.11 .2020
Accepted: 24.12 .2020
Published: 04.06 .2021 
ent types of pterion and to determine its exact location in dry adult human crania and to determine the variation in pteria between two sides and between males and females.

\section{MATERIALS AND METHODS}

A Cross-sectional observational study was conducted in the Department of Anatomy, Kalinga Institute of Medical Sciences. 50 human crania (100 pteria) of known sex i.e 40 male and 10 female, were used for the study. The pattern of pteria, their shape and variations between male and female were analyzed. The measurements were taken using a digital vernier calliper on the norma lateral side. The study was approved by Institutional Ethics Committee [IEC approval No. KIIT/ KIMS/IEC/51/2019].

Position of pterion was measured as the distance from bony landmarks such as Frontozygomatic suture (Figure 5) and the midpoint of the superior border of the zygomatic arch (Figure 4). Percentages of different morphological types of pterion such as Sphenoparietal type, Frontotemporal type, Stellate type and Epipteric type was evaluated. Variations in position and type were compared between both sides and between males and females.

Inclusion Criteria: Adult dry human crania, No trauma/ fracture/deformity, Sutures visible. Exclusion Criteria: Crania with evidence of trauma/fracture/deformity, Sutures fused and not visible.

\section{RESULTS}

\section{Types}

The most common type of pterion was Sphenoparietal (80\%) followed by Epipteric (10\%), Stellate (10\%) and Frontotemporal $(0 \%)$ types shown in Table 1.

\section{Comparison between sides}

Distance between Pterion and Frontozygomatic suture on the right side was $29.5 \pm 3.97 \mathrm{~mm}$ and on the left side, it was $28.3 \pm 4.39 \mathrm{~mm}$. There was no significant difference between both sides ( $\mathrm{p}=0.15$ shown in Table 2 .

Distance between Pterion and Midpoint of the upper border of the zygomatic arch was $38.11 \pm 3.35 \mathrm{~mm}$ on the right side and $37.11 \pm 3.38 \mathrm{~mm}$ on the left side. There was no significant difference between both sides $(\mathrm{p}=0.14)$ in Table 3 .

\section{Comparison between gender}

The distance between pterion and frontozygomatic suture in males was $29.17 \pm 4.34 \mathrm{~mm}$ and in females, it was $27.86 \pm$ $3.53 \mathrm{~mm}$. There was no significant difference between gen$\operatorname{der}(\mathrm{p}=0.21)$ in Table 2 .
The distance between pterion and Midpoint of the upper border of the zygomatic arch was $38.22 \pm 3.25 \mathrm{~mm}$ in males and $35.25 \pm 2.88 \mathrm{~mm}$ in females. There was a significant difference between the two sexes $(\mathrm{p}=0.00033)$ in Table 3 .

\section{DISCUSSION}

In all studies of pterion conducted by investigators worldwide it has been found that the most common type of pterion encountered is sphenoparietal. Epipteric was the second common type in studies conducted by Praba (2012) and Sarvaiya (2019). ${ }^{4,8}$ Frontotemporal was the second common type in studies conducted by Oguz (2004), Kumar (2013) and Ukoha (2013) but is was the least common in Srinivasa's study (2016) in Table 4.,3,5,7

In our study, the most common type was Sphenoparietal similar to previous studies, followed by epipteric and stellate types in equal proportions. The minor variation in observation of other types may be due to geographical, racial and genetic factors. In all studies, there was no significant side difference in the distance between pterion and frontozygomatic suture and the distance between pterion and midpoint of the superior border of the zygomatic arch. In our study, there was a similar finding in Table 5.

There was no significant gender difference in the distance between pterion and frontozygomatic suture but the distance between pterion and midpoint of the superior border of zygomatic arch showed significant differences between male and female $(\mathrm{p}=0.00033)$.

\section{CONCLUSION}

The importance of pterion in neurosurgical interventions cannot be overlooked. Accessory sutural bone is important for radiologist and neurosurgeons while interpreting through $\mathrm{x}$ rays or surgical correction of a fracture..$^{14} \mathrm{An}$ anthropometric database of the different types and different positions of pteria can be made which will help anatomist, anthropologist and forensic experts in the field. Helmet manufacturing companies/Policymakers may take note of the position of pterion, as it is a common site of skull fracture in Road Traffic Accidents and manufacture of helmets for males and females of Odisha with appropriate size adjustments and additional soft padding over the region of pterion for extra protection can be done.

\section{ACKNOWLEDGEMENT}

We are grateful to the Head of the Department of Anatomy of Kalinga Institute of Medical Sciences for allowing me to use the skull bones for this study. We thank the technical staff 
of the Anatomy Department of Kalinga Institute of Medical Sciences for their assistance. We thank the authors, reviewers and publishers of all the articles which we have used for our reference. We immensely thank the Editorial Board Members and the Team of Reviewers of IJCRR for their valuable input and guidance because of which the manuscript could be brought to its final form.

Conflict of interest: There is no conflict of interest.

Funding source: NIL

\section{REFERENCES}

1. Standring S, Gray's Anatomy: The Anatomical Basis of Clinical Practice. $41^{\text {st }}$ ed. Edinburg. Elsevier, Churchill Livingstone. 409-43.

2. Thomas M. The Pterion in the Australian Aborigine. Am J Phys Anthropol. 1956;14(2):225-44.

3. Oguz O, Sanli SG, Bozkir MG, Soames RW. The Pterion in Turkish male skulls. Surg Radiol Anat. 2004; 26(3):220-4.

4. Praba AMA, Venkatramaniah C. Morphometric study of different types of pterion and its relation with a middle meningeal artery in dry skulls of Tamil Nadu. J Pharm Biomed Sci. 2012;21(04):1-4.

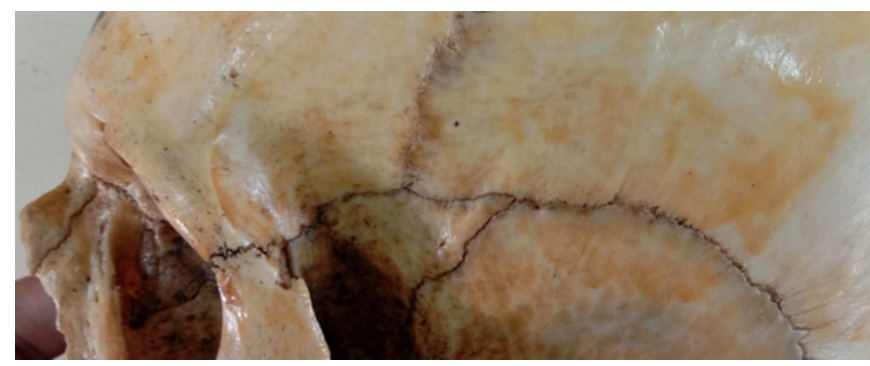

Figure 1: Sphenoparietal Type.

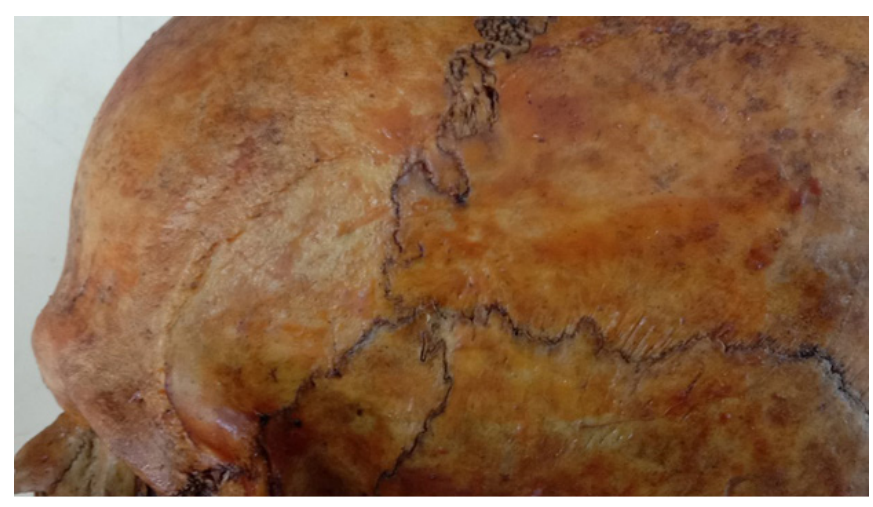

Figure 2: Stellate type.
5. Kumar S, Anurag, Munjal S, Chauhan P, Chaudhary A, Jain SK. Pterion its location and clinical implications - A study compared. J Evol Med Dent Sci. 2013;2(25):4600-8.

6. Ukoha U, Oranusi CK, Okafor JI, Udemezue OO, Anyabolu AE, Nwamarachi TC. Anatomic study of the pterion in Nigerian dry human skulls. Niger J Clin Pract. 2013;16(3):325-8.

7. Srinivasa RY, Eswari AK, Swayam JS, Rajeswara RN. Morphology of Pterion. Int J Sci Res. 2016;5(8):650-1.

8. Sarvaiya BJ, Chaudhari JS, Fichadiya NC. Morphometric analysis of pterion in the adult human dry skull of Gujarat region. Int J Anat Res. 2019;7(1.2):6204-10.

9. Sunday AA, Funmilayo EO, Modupe B. Study of the location and Morphology of the Pterion in Adult Nigerian Skulls. Int Sch Res Notices. 2013;403937:1-4.

10. Aksu F, Akyer SP, Kale A, Geylan S, Gayretli O. The Localization and Morphology of pterion in adult west Anatolian skulls. J Craniofac Surg. 2014;25(4):1488-91.

11. Gindha GS, Mir NS, Agarwal R. Morphometric study of Pterion in dry human skull bone in North Indian Population. Hum Biol Rev. 2017;6(1):1-9.

12. Kulkarni P, Sukre S, Muley M. Morphometric study of Pterion in dry adult human skulls. Int J Anat Res. 2017;5(3.3):4365-4368.

13. Nayak G, Mohanty BB, Das SR. Morphometric study of Pterion and its clinical significance. Asian J Pharm Clin Res. 2017;10(10):142-4.

14. Sudha R, Sridevi C, Ezhilarasi M. Anatomical variations in the formation of Pterion and Asterion in South Indian population. Int J Curr Res Rev. 2013;5(9):92-101.

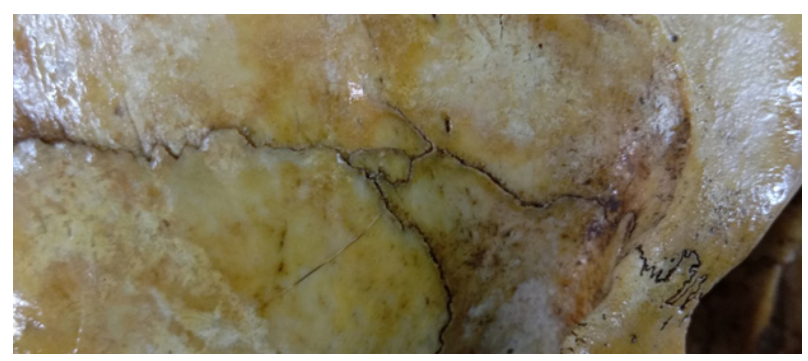

Figure 3: Epipteric type.

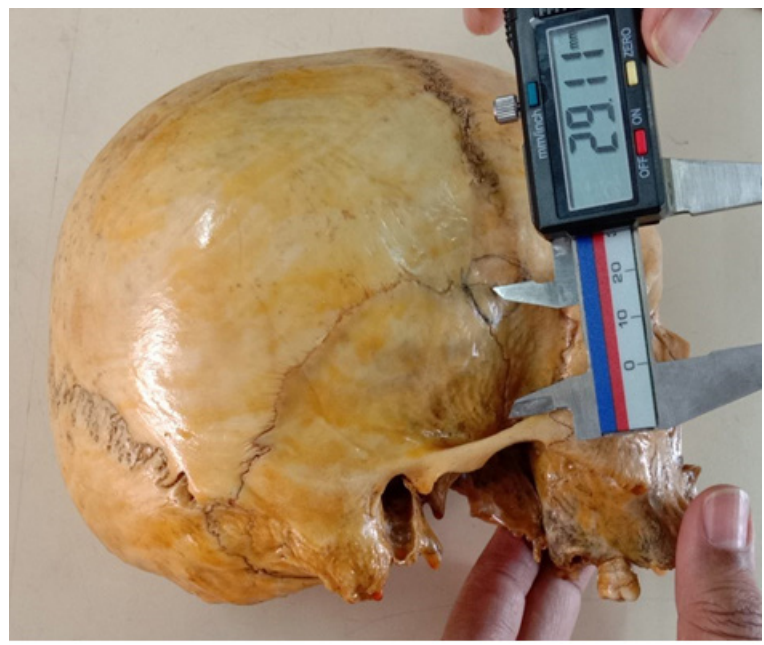

Figure 4: Measurement of Distance between Pterion and Midpoint of upper border of Zygomatic arch. 


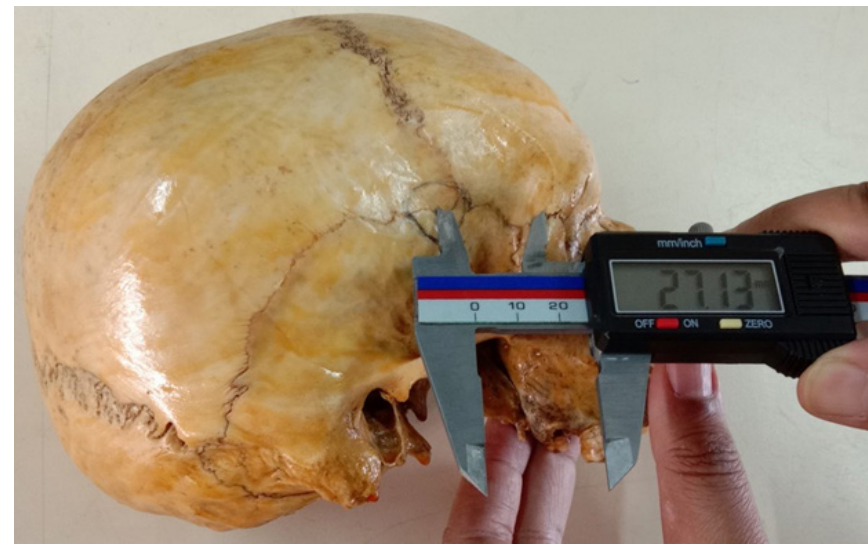

Figure 5: Measurement of distance between Pterion and Frontozygomatic suture.

Table 1: Types of pterion and their percentages.

\begin{tabular}{|c|c|c|c|c|}
\hline Type & $\begin{array}{l}\text { Sphenopa- } \\
\text { rietal }(\mathbf{8 0} \%)\end{array}$ & $\begin{array}{c}\text { Epipteric } \\
(10 \%)\end{array}$ & $\begin{array}{c}\text { Stellate } \\
(10 \%)\end{array}$ & $\begin{array}{c}\text { Frontotem- } \\
\text { poral }(\mathbf{0} \%)\end{array}$ \\
\hline
\end{tabular}

Side Right Left Right Left Right Left Right Left

\begin{tabular}{lllllllll}
$\mathrm{N}$ & 40 & 40 & 6 & 4 & 5 & 5 & $\mathrm{o}$ & $\mathrm{o}$ \\
\hline
\end{tabular}

Table 2: Distance between pterion and Frontozygomatic suture (Mean \pm SD) in $\mathrm{mm}$.

\begin{tabular}{llll}
$\begin{array}{l}\text { Comparison between } \\
\text { sides }\end{array}$ & \multicolumn{2}{l}{ Comparison between sexes } \\
Right & Left & Male & Female \\
$29.5 \pm 3.97$ & $28.3 \pm 4.39$ & $29.17 \pm 4.34 \mathrm{~mm}$ & $27.86 \pm 3.53$ \\
$\mathrm{~mm}$ & $\mathrm{~mm}$ & $\mathrm{~mm}$ \\
p value $=0.15$ & & p value $=0.21$ \\
\hline
\end{tabular}

Table 3: Distance between pterion and mid point of superior border of zygomatic arch (Mean $\pm S D$ ) in mm.

\begin{tabular}{lccc}
\multicolumn{2}{l}{ Comparison between sides } & \multicolumn{2}{c}{$\begin{array}{c}\text { Comparison between } \\
\text { sexes }\end{array}$} \\
Right & Left & Male & Female \\
$38.11 \pm 3.35 \mathrm{~mm}$ & $\begin{array}{c}37.11 \pm 3.38 \\
\mathrm{~mm}\end{array}$ & $\begin{array}{c}38.22 \pm 3.25 \\
\mathrm{~mm}\end{array}$ & $\begin{array}{c}35.25 \pm 2.88 \\
\mathrm{~mm}\end{array}$ \\
& & & $\mathrm{p}$ value $=0.00033$ \\
\hline
\end{tabular}

Table 4: Comparision of types of pteria in previous studies and present study

\begin{tabular}{|c|c|c|c|c|c|c|c|c|c|c|}
\hline \multirow[t]{2}{*}{ S1. No. } & \multirow{2}{*}{$\begin{array}{l}\text { N (No. of Pteria) \& } \\
\text { Population }\end{array}$} & \multicolumn{2}{|c|}{ Sphenoparietal } & \multicolumn{2}{|c|}{ Epipteric } & \multicolumn{2}{|c|}{ Frontotemporal } & \multicolumn{2}{|c|}{ Stellate } & \multirow[t]{2}{*}{ Reference } \\
\hline & & Right & Left & Right & Left & Right & Left & Right & Left & \\
\hline 1. & $\begin{array}{l}52 \\
\text { (Turkish Male) }\end{array}$ & 96 & 79 & - & 4 & 4 & 17 & - & - & Oguz $(2004)^{3}$ \\
\hline 2. & $\begin{array}{l}100 \\
\text { (Tamil Nadu) }\end{array}$ & 78 & 70 & 10 & 18 & 2 & 4 & 10 & 8 & Praba $(2012)^{4}$ \\
\hline 3. & $\begin{array}{l}\text { 8o } \\
\text { (Dehradun) }\end{array}$ & 90 & 82.5 & - & - & 12.5 & 10 & 5 & o & $\operatorname{Kumar}(2013)^{5}$ \\
\hline 4. & $\begin{array}{l}112 \\
\text { (Nigerian) }\end{array}$ & 75 & 76 & 3.6 & 3.6 & 19.6 & 19.6 & 1.8 & o & Ukoha $(2013)^{6}$ \\
\hline 5. & $\begin{array}{l}112 \text { (Kancheepuram } \\
\text { Dist.) }\end{array}$ & 33 & 33 & 8 & 2.6 & 1.7 & 0.8 & 6.2 & $5 \cdot 3$ & Srinivasa $(2016)^{7}$ \\
\hline 6. & $\begin{array}{l}652 \\
\text { (Gujarat) }\end{array}$ & 81.59 & 78.83 & 9.82 & 11.96 & 4.91 & $5 \cdot 52$ & 3.68 & 3.68 & Sarvaiya $(2019)^{8}$ \\
\hline 7. & $\begin{array}{l}100 \\
\text { (Odisha) }\end{array}$ & 40 & 40 & 6 & 4 & o & o & 5 & 5 & Present study \\
\hline
\end{tabular}

Table 5: Comparision in Variations in location of Pteria

\begin{tabular}{|c|c|c|c|c|c|c|c|}
\hline \multirow[t]{2}{*}{$\begin{array}{l}\text { Sl. } \\
\text { No. }\end{array}$} & \multirow[t]{2}{*}{ N \& Population } & \multicolumn{2}{|c|}{$\begin{array}{l}\text { Pterion-Frontozygomatic Suture } \\
(\mathbf{m m})(\text { Mean } \pm \text { SD })\end{array}$} & \multicolumn{2}{|c|}{$\begin{array}{l}\text { Pterion-Zygomatic arch } \\
\quad(\mathbf{m m})(\text { Mean } \pm \text { SD })\end{array}$} & \multirow[t]{2}{*}{ P value } & \multirow[t]{2}{*}{ Reference } \\
\hline & & Right & Left & Right & Left & & \\
\hline 1. & $\begin{array}{l}52 \\
\text { Turkish Males }\end{array}$ & $33.0 \pm 4.0$ & $34.4 \pm 3.9$ & $40.5 \pm 3.9$ & $38.5 \pm 2.5$ & - & Oguz $(2004)^{3}$ \\
\hline 2. & $\begin{array}{l}74 \\
\text { Nigera }\end{array}$ & $31.52 \pm 0.677$ & $30.82 \pm 0.809$ & $39.1 \pm 0.583$ & $38.77 \pm 0.631$ & $0.505,0.704$ & $\begin{array}{l}\text { Adejuwon } \\
(2013)^{9}\end{array}$ \\
\hline 3. & $\begin{array}{l}112 \\
\text { Nigeria }\end{array}$ & $27.4 \pm 0.70$ & $27.4 \pm 0.60$ & $40.2 \pm 0.50$ & $40.1 \pm 0.30$ & - & Ukoha $(2013)^{6}$ \\
\hline
\end{tabular}


Table 5: (Continued)

\begin{tabular}{|c|c|c|c|c|c|c|c|}
\hline \multirow[t]{2}{*}{$\begin{array}{l}\text { S1. } \\
\text { No. }\end{array}$} & \multirow[t]{2}{*}{ N \& Population } & \multicolumn{2}{|c|}{$\begin{array}{l}\text { Pterion-Frontozygomatic Suture } \\
(\mathbf{m m})(\text { Mean } \pm \text { SD })\end{array}$} & \multicolumn{2}{|c|}{$\begin{array}{l}\text { Pterion-Zygomatic arch } \\
(\mathrm{mm})(\text { Mean } \pm \text { SD })\end{array}$} & \multirow[t]{2}{*}{ Pvalue } & \multirow[t]{2}{*}{ Reference } \\
\hline & & Right & Left & Right & Left & & \\
\hline 4. & $\begin{array}{l}256 \\
\text { West Anatolian }\end{array}$ & $31.80 \pm 4.51$ & $31.44 \pm 4.73$ & $40.02 \pm 4.06$ & $39.88 \pm 4.01$ & - & Aksu $(2014)^{10}$ \\
\hline 5. & $\begin{array}{l}80 \\
\text { Dehradun }\end{array}$ & $32.5 \pm 10.5$ & $32.5 \pm 10.5$ & $38.25 \pm 6.25$ & $37.0 \pm 7.0$ & $0.438,0.275$ & Kumar (2013) $)^{5}$ \\
\hline 6. & $\begin{array}{l}130 \\
\text { Himachal } \\
\text { Pradesh }\end{array}$ & $38.71 \pm 3.10$ & $36.29 \pm 3.73$ & $39 \pm 2.56$ & $37 \pm 3.34$ & - & Gindha $(2016)^{11}$ \\
\hline 7 . & $\begin{array}{l}72 \\
\text { Maharastra }\end{array}$ & $29.81 \pm 4.42$ & $29.81 \pm 4.07$ & $37.16 \pm 3.77$ & $37.56 \pm 3.71$ & - & $\begin{array}{l}\text { Kulkarni } \\
(2017)^{12}\end{array}$ \\
\hline 8. & $\begin{array}{l}100 \\
\text { Bhubaneswar }\end{array}$ & $34.8 \pm 2.1$ & $34.1 \pm 1.6$ & $40.1 \pm 1.9$ & $39.4 \pm 2.0$ & $>0.5$ & Nayak (2017) \\
\hline 9. & $\begin{array}{l}652 \\
\text { (Gujarat) }\end{array}$ & $30.17 \pm 3.91$ & $29.23 \pm 3.85$ & $37.36 \pm 3.62$ & $36.34 \pm 3.54$ & - & Sarvaiya $(2019)^{8}$ \\
\hline 10. & $\begin{array}{l}100 \\
\text { (Odisha) }\end{array}$ & $29.5 \pm 3.97$ & $28.3 \pm 4.39$ & $38.11 \pm 3.35$ & $37.11 \pm 3.38$ & $\mathrm{P}=0.15,0.14$ & Present study \\
\hline
\end{tabular}

